\title{
Zrobotyzowane spawanie wielkogabarytowych elementów ze wspomaganiem programowania off-line
}

\author{
Robot montioned large structures welding \\ with off-line support programing
}

\section{Streszczenie}

W artykule przedstawiono nowoczesne technologie oraz innowacyjne funkcje programistyczne wspomagające programowanie robotów marki Panasonic do spawania konstrukcji wielkogabarytowych. Jako przykład przedstawiono proces produkcyjny słupów energetycznych.
Abstract

The paper presents new technologies and innovative software functions which support programming of Panasonic robots for welding large structures. As an example the production process of energetic pillars will be used.

\section{Wstęp}

Spawanie wielkogabarytowych konstrukcji stalowych znajduje zastosowanie głównie w przemyśle stoczniowym (budowa i renowacja okrętów), offshore (platformy do wydobycia gazu i ropy), energetycznym (elektrownie wiatrowe, słupy energetyczne), przy produkcji mostów oraz różnorodnych maszyn budowlanych czy górniczych. Wytworzenie tak dużych elementów wiąże się z olbrzymim nakładem finansowym, na który składają się m.in.: koszty materiałów, przygotowania produkcji i czas pracy operatorów. Dlatego ważnym czynnikiem jest dobranie odpowiedniej technologii produkcji zapewniającej optymalizację ekonomiczną procesu. Zastosowane materiały powinny spełniać wymagania wytrzymałościowe zaprojektowanej konstrukcji według określonej normy, a jednocześnie powinny być użyte w ilościach oraz gabarytach zapewniających dobrą ekonomikę procesu.

Wykonywanie elementów wielkogabarytowych metodami ręcznymi i mało zmechanizowanymi jest praco-

Inż. Mirosław Nowak (EWE), mgr inż. Jacek Buchowski, mgr inż. Daniel Wiśniewski (IWE) - Technika Spawalnicza, Poznań. chłonne (długie spoiny wielościegowe), mało wydajne, a nawet niebezpieczne dla zdrowia operatora. Personel musi pracować $w$ trudnych warunkach, spawając wysokimi parametrami, niekiedy na dużych wysokościach lub wewnątrz ciasnych konstrukcji. Wykonywane spoiny nie są powtarzalne, a ich jakość często nie spełnia oczekiwań klienta końcowego, a także wymagań odpowiednich poziomów jakości. Dlatego przy tego typu zadaniach zaleca się wyeliminowanie prac ręcznych i zastąpienie ich procesem zautomatyzowanym lub zrobotyzowanym. Zastosowanie znajdują tutaj wszelkiego rodzaju automaty spawalnicze wykonujące proste, z góry określone operacje łączenia metali, oraz roboty spawalnicze, które są zdecydowanie bardziej uniwersalnymi urządzeniami pozwalającymi na przeprowadzenie dowolnej trajektorii ruchu palnika (rys. 1).

W dotychczasowej praktyce opanowano z powodzeniem technologię spawania spoin wzdłużnych i obwodowych (zbiorniki, rurociagii) metodami MIG/MAG oraz łukiem krytym SAW zarówno na automatach jak i na robotach. Jednak olbrzymie trudności stwarza spawanie elementów o skomplikowanym przekroju poprzecznym. W tym przypadku proste automaty spawalnicze nie znajdą zastosowania, ponieważ trajektoria ruchu palnika jest bardziej złożona. 


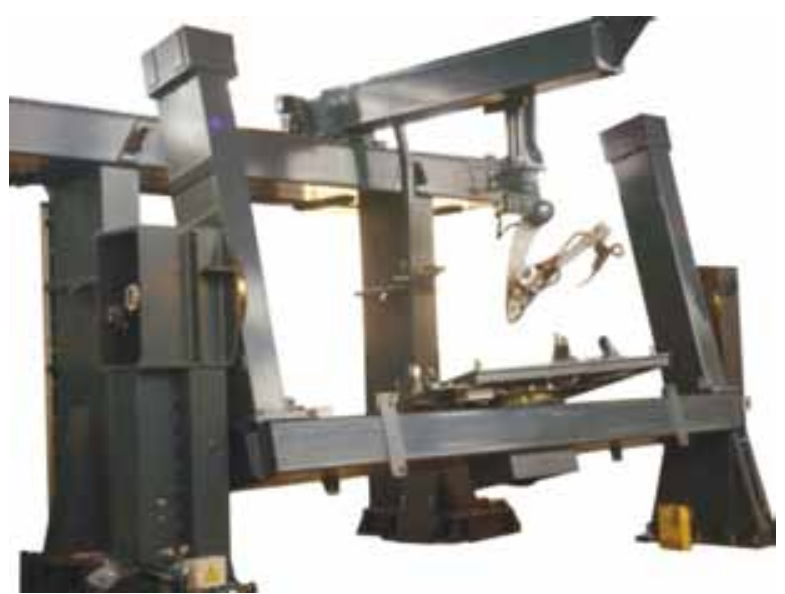

Rys. 1. Przykładowe stanowisko do spawania elementów wielkogabarytowych z robotem Panasonic

Fig. 1. Example system for welding large structure with Panasonic robot

Kolejną napotykaną przeszkodą przy zrobotyzowanym spawaniu konstrukcji wielkogabarytowych są spoiny wielościegowe. Przy tego typu połączeniach zachodzi potrzeba wprowadzania wielu punktów uczenia robota z różną pozycją i orientacją palnika dla każdego ściegu odrębnie. Dlatego firma Panasonic opracowała dodatkowy software oraz hardware Thick Plate dla swoich robotów, który wspomaga programowanie procesu spawania grubych blach łączonych spoinami wielościegowymi. Dzięki temu praca programisty została ograniczona jedynie do napisania pierwszego ściegu i określenia liczby kolejnych ściegów w spoinie z dobranymi odpowiednio parametrami spawania.

W przypadku wystąpienia niedokładności w przygotowaniu elementów do spawania, co jest często spotykanym problemem przy produkcji elementów wielkogabarytowych, należy doposażyć roboty w odpowiednie sensory (dotyku oraz łuku). Standardowe sensory wykorzystywane w przemyśle produkcyjnym opierają się na dwóch metodach lokalizacji przesunięcia linii złącza: pierwsza, taktylna zakłada pomiar przez dotyk i zwarcie dyszy gazowej lub drutu elektrodowego z elementem spawanym, natomiast druga wykorzystuje ruch oscylacyjny robota oraz zmiany napięcia łuku elektrycznego przy wydłużeniu lub skróceniu wolnego wylotu elektrody.

\section{Zalety programowania off-line elementów wielkogabarytowych}

Programowanie robotów do spawania elementów o dużych gabarytach jest często utrudnione przez ograniczony dostęp do miejsc spawanych.

Operator w takim przypadku zmuszony jest do korzystania z drabin, podestów czy nawet zwyżek, co znacznie wydłuża czas prac programistycznych, testów oraz naraża go na dodatkowe niebezpieczeństwo.
Dlatego firma Panasonic opracowała specjalny program wirtualny DTPS (Desk Top Programming \& Simulation System) do pracy off-line (poza robotem). Program DTPS znacznie przyspiesza również proces dodawania nowych punktów uczenia robota, ponieważ nie ma potrzeby powolnego przesuwania ramienia w celu zapisania punktu, jak ma to miejsce w rzeczywistym systemie, kiedy jesteśmy w trybie uczenia TE$\mathrm{ACH}$. Na detalu wirtualnym wystarczy zaznaczyć punkt charakterystyczny, a pozycja i orientacja robota zostaną zapisane automatycznie.

Przy użyciu skrótów klawiaturowych na komputerze znacznie przyspieszona jest również edycja programu spawalniczego, w którym np. musimy dokonać przesunięcia punktów o zadaną odległość w układzie kartezjańskim $(X, Y, Z)$ lub układzie narzędzia (palnika). Natomiast edycja parametrów spawalniczych czy poleceń dodatkowych jest przyspieszona z uwagi na korzystanie z pełnej klawiatury alfanumerycznej na komputerze.

DTPS dzięki swojej strukturze aktywnych okien daje przejrzystość kodu podczas pisania programu. Na bieżąco wyświetlane są pozycje robota i osi zewnętrznych, wartości zmiennych czy kierunki układów współrzędnych, wzdłuż których przesuwamy ramię robota. Dodatkowo zagnieżdżenie wszelkich okien podglądu możemy dowolnie modyfikować według własnych preferencji (rys. 2).

Możliwe jest także wirtualne ustawienie kolizyjności poszczególnych części ramienia robota z otaczającymi go przedmiotami, co gwarantuje wierne oddanie warunków rzeczywistego systemu. Po wykryciu kolizji program wyświetla komunikat informujący, które elementy miały kolizję. Jest to niewątpliwie dużym atutem przy programowaniu off-line, ponieważ kolizja na rzeczywistym systemie może powodować uszkodzenie sprzętu, za którym idą wysokie koszty serwisowe lub spowodować zagrożenie dla życia operatora.

Korzystając z oprogramowania DTPS, nie trzeba przerywać procesu produkcyjnego. Kiedy robot wykonuje zadany cykl pracy w tym samym czasie operator może przygotowywać kolejny program roboczy lub edytować istniejący. Dla przykładu przeanalizujmy spawanie tylko jednego ściegu spoiny obwodowej słupa energetycznego. Zakładając, że słup ma 3 m średnicy, a prędkość spawania wynosi $0,3 \mathrm{~m} / \mathrm{min}$, to czas spawania wynosi $30 \mathrm{~min}$. W całym procesie jest min.7 takich ściegów obwodowych, co daje 3,5 h ciągłego spawania. Tak więc czas ten operator może poświęcić efektywnie na programowanie off-line. Takie rozwiązanie sprawdza się również przy produkcji jednostkowej, w której należy poświęcić dużo czasu i na pisanie programów, i na cykl roboczy. W opisywanym przykładzie spawania słupów energetycznych taka sytuacja ma również miejsce. Każdy słup wykonywany jest na specjalne zamówienie klienta i ma inną średnicę, grubość ścianek oraz ułożenie żeber wzmacniających. Dlatego wszystkie programy pisane są indywidualnie po otrzymaniu przez operatora rysunków technicznych słupa. 


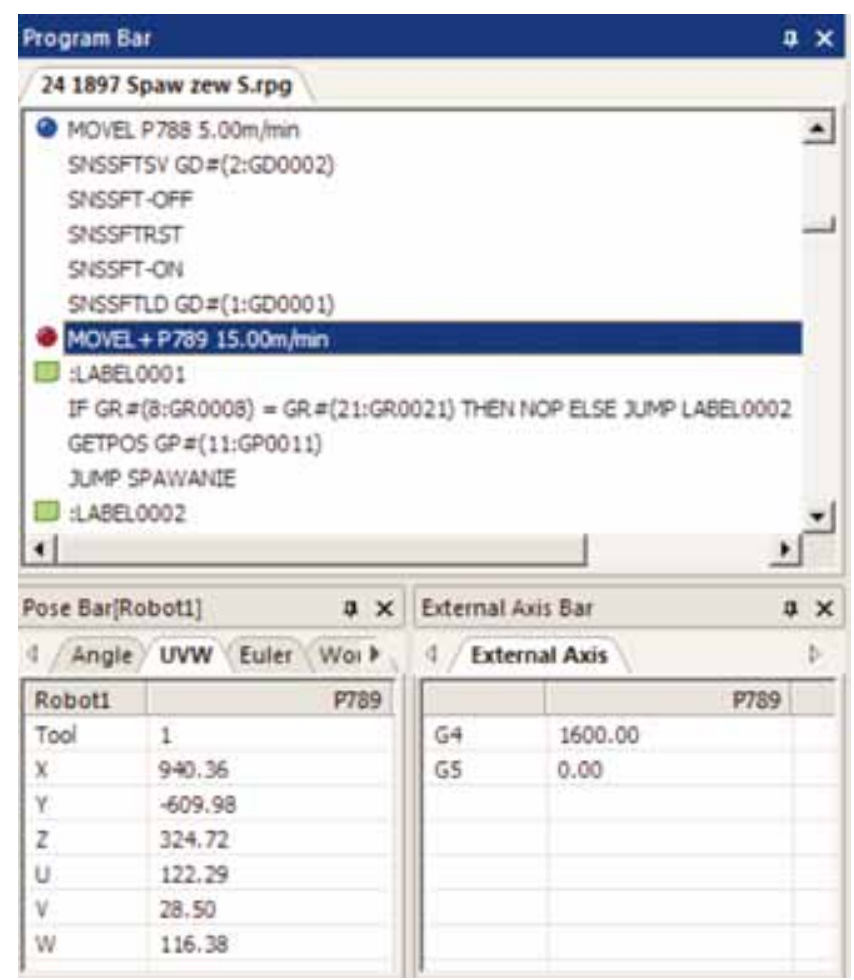

Rys. 2. Okno główne z podglądem kodu programu oraz dwa mniejsze $z$ podglądem pozycji robota i osi zewnętrznych

Fig. 2. The main window with a preview of the program code, and two smaller ones with a preview of the robot position and external axes position

Koleją zaletą programowania off-line jest automatyczne obliczanie całkowitego czasu trwania cyklu. Program podaje w sekundach czas ruchów spawalniczych i jałowych oraz procentowy udział ruchów spawalniczych w całym procesie. Natomiast w rzeczywistym systemie robot najpierw musiałby wykonać cały cykl, aby mógł następnie wyświetlić informację o jego czasie trwania. DTPS dodatkowo udostępnia informację o liczbie i długości wykonywanych spoin, a najnowsza wersja oprogramowania podaje długość zużytego drutu elektrodowego liczoną w metrach.

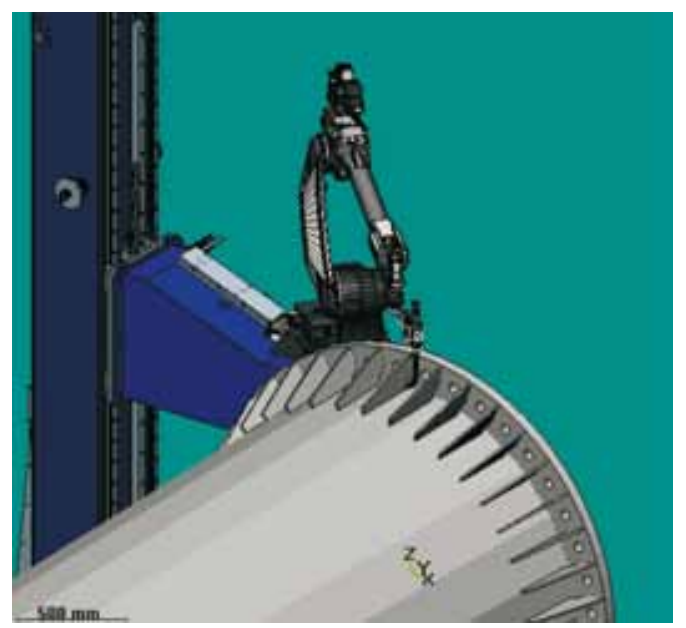

Rys. 3. Robot spawający jedno z żeber wzmacniających podstawę słupa energetycznego

Fig. 3. Robot is welding one of reinforcing ribs on the base of energetic pillar
Jako przykład obliczenia czasu cyklu przedstawiono spawanie jednego żebra wzmacniającego podstawę słupa energetycznego (rys. 3). Czas cyklu uwzględnia:

- czas ruchów jałowych,

- czas ruchów spawalniczych - położenie 8 spoin (4 spoiny w pozycji PB, 2 spoiny w pozycji PG i 2 spoiny w pozycji PF),

- czas potrzebny na zlokalizowanie żebra sensorem dotyku.

Przyjęto również następujące założenia:

- prędkość spawania dla 6 spoin wynosi $0,3 \mathrm{~m} / \mathrm{min}$, dla 2 pozostałych $0,1 \mathrm{~m} / \mathrm{min}$,

- prędkość ruchów jałowych wynosi $50 \mathrm{~m} / \mathrm{min}$,

- prędkość szukania sensorem dotyku 0,9 $\mathrm{m} / \mathrm{min}$, Otrzymano następujące wyniki (rys. 4) z analizy procesu spawania żeber wzmacniających:

- całkowity czas - $585 \mathrm{~s}$ (ok. 9,7 min),

- czas spawania - 552 s (ok. 9,2 min),

- procentowy udział czasu spawania - 94,4\%,

- długość całkowita wszystkich spoin - 2375 mm

- liczba spoin - 8.

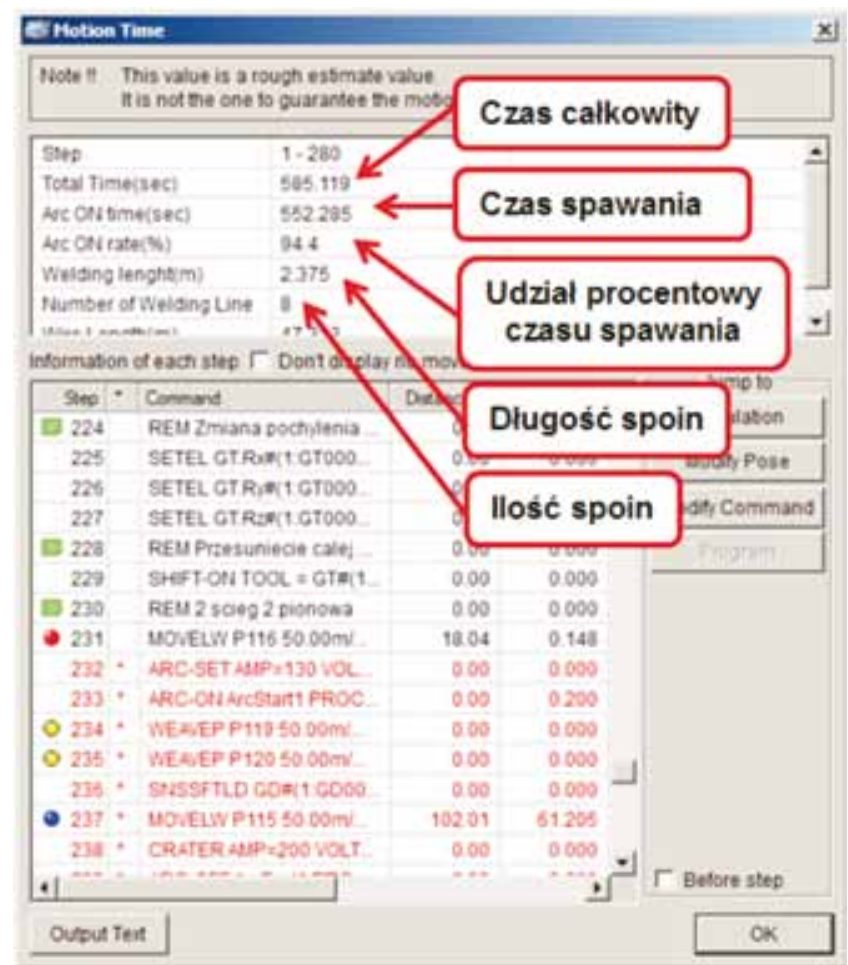

Rys. 4. Analiza czasu trwania jednego cyklu spawania żebra wzmacniającego

Fig. 4. Analysis of one welding cycle time of the reinforcing rib

\section{Funkcje programowe wspomagające zrobotyzowane spawanie elementów wielkogabarytowych}

\section{Struktura oprogramowania G2/G3PCTool}

G2/G3PCTool jest specjalistycznym oprogramowaniem służącym do tworzenia wirtualnych zrobotyzowanych 
systemów spawalniczych Panasonic. W jego skład wchodzą następujące narzędzia:

- Virtual Robot (rys. 5) - służy do przechowywania tzw. backup'u czyli ustawień systemowych rzeczywistego robota oraz programów wykonawczych,

- PC Folder (rys. 6) - magazyn folderów i podfolderów do przechowywania plików niezbędnych do stworzenia wirtualnego stanowiska zrobotyzowanego,

- Parts Editor (rys. 7) - służy do projektowania elementów płaskich oraz brył przestrzennych z możliwością importowania plików z zewnętrznych programów CAD. Możemy za jego pomocą narysować takie elementy jak detal spawany, przyrządy ustalająco-mocujące czy zabudowa ochronna stanowiska;

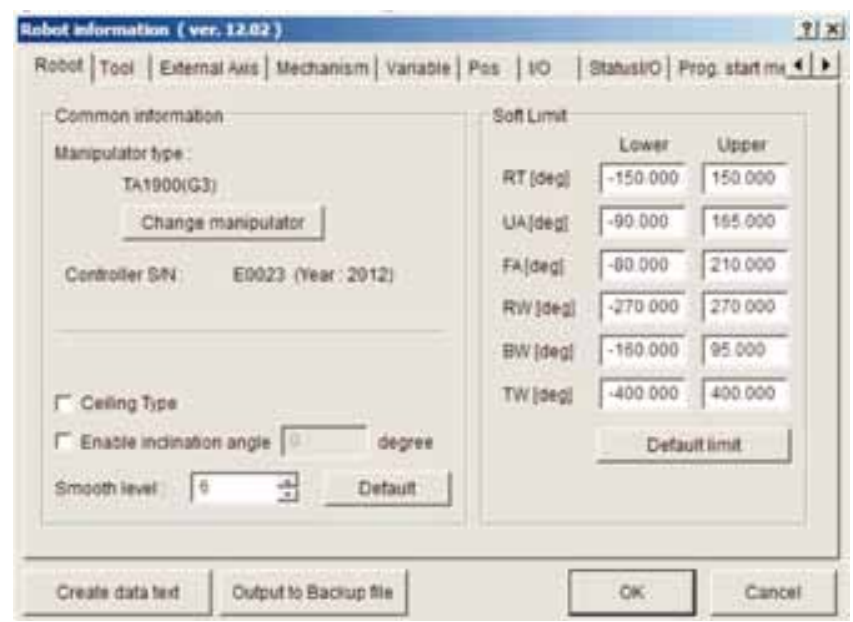

Rys. 5. Narzędzie Virtual Robot

Fig. 5. Virtual Robot tool

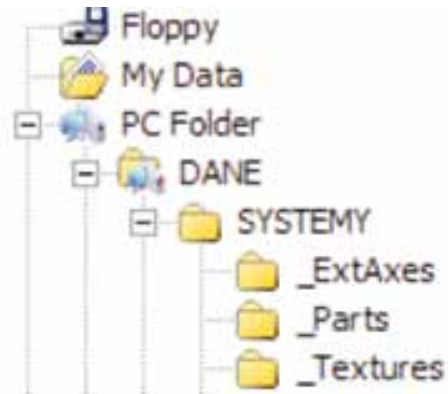

Rys. 6. Magazyn folderów - PC Folder

Fig. 6. Storage folder - PC Folder

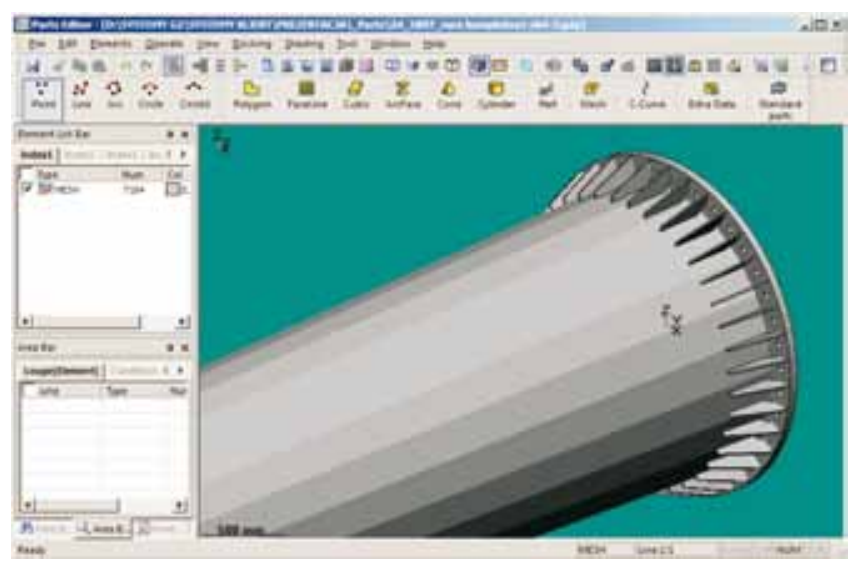

Rys. 7. Edytor części - Parts Editor

Fig. 7. Parts Editor
- ExternalAxis Editor (rys. 8) - tworzy się za jego pomocą zewnętrzne osie robota. Mogą to być różnego rodzaju osie obrotowe lub obrotowo-przechylne jak pozycjonery oraz osie przesuwne jak tory jezdne czy słupowysięgniki. W przedstawionym przykładzie stworzono wirtualny słupowysięgnik o płynnym ruchu w osi pionowej w zakresie $0-2800 \mathrm{~mm}$ oraz poziomą oś obrotową, która obraca element spawany wokół jego osi. W rzeczywistym układzie zastosowano obrotnik rolkowy, którego włączenie powoduje obrót dwóch rolek jednocześnie w jednym kierunku (funkcja GantryPair),

- Installation Editor (rys. 9) - w edytorze tym tworzymy instalację zawierającą odpowiedni typ ramienia robota, przypisujemy zdefiniowane wcześniej w ExternalAxis Editor osie zewnętrzne oraz określamy m.in. rodzaj podajnika drutu czy palnika.

- DTPS (Desk Top Programming \& Simulation System) - służy do pisania programów spawalniczych i wykonawczych metodą off-line (rys. 10). Udostępnia wszystkie funkcje, które posiada rzeczywisty robot, dzięki którym możemy wygenerować trajektorię z dowolną interpolacją ruchu robota, wstawić parametry spawania oraz polecenia dodatkowe.

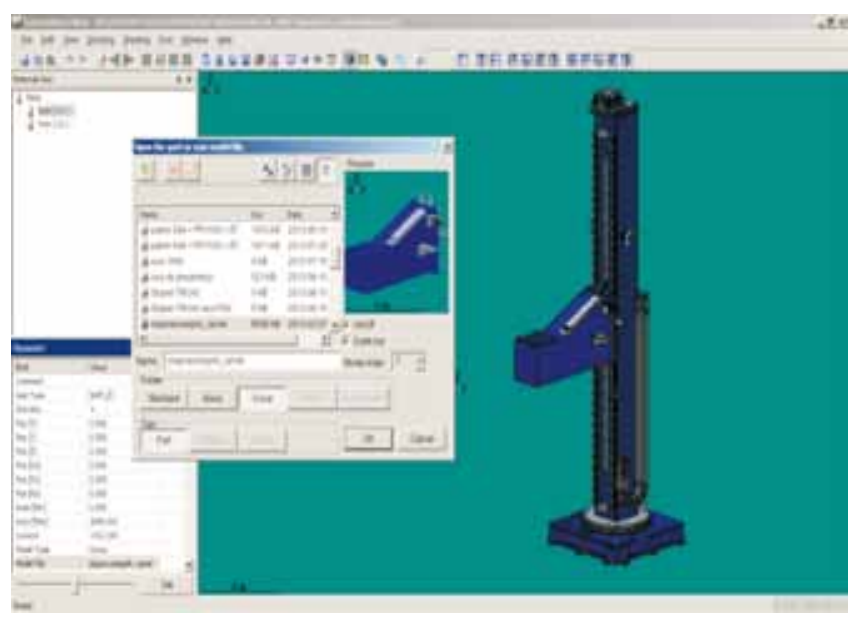

Rys. 8. Edytor osi zewnętrznych - ExternalAxis Editor

Fig. 8. Editor of external axis - ExternalAxis Editor

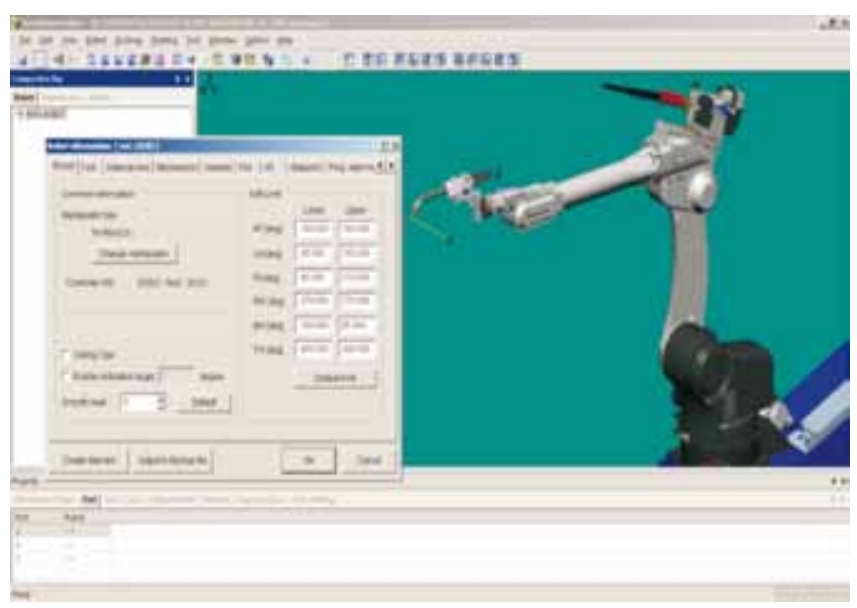

Rys. 9. Edytor instalacji systemu - Installation Editor

Fig. 9. Editor of system installation - Instalation Editor 


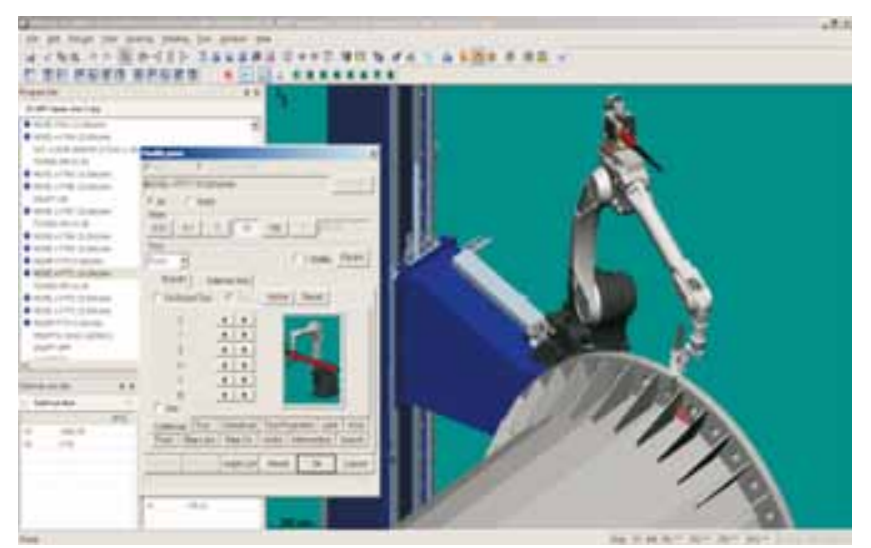

Rys. 10. Program G2/G3 DTPS Fig. 10. G2/G3 DTPS program

W rezultacie, korzystając z wszystkich powyżej opisanych narzędzi można stworzyć wirtualne stanowisko zrobotyzowane (rys. 12), które jednoznacznie odwzorowuje stanowisko rzeczywiste (rys. 11) w warstwie wizualnej,jak też pod względem ustawień systemowych.

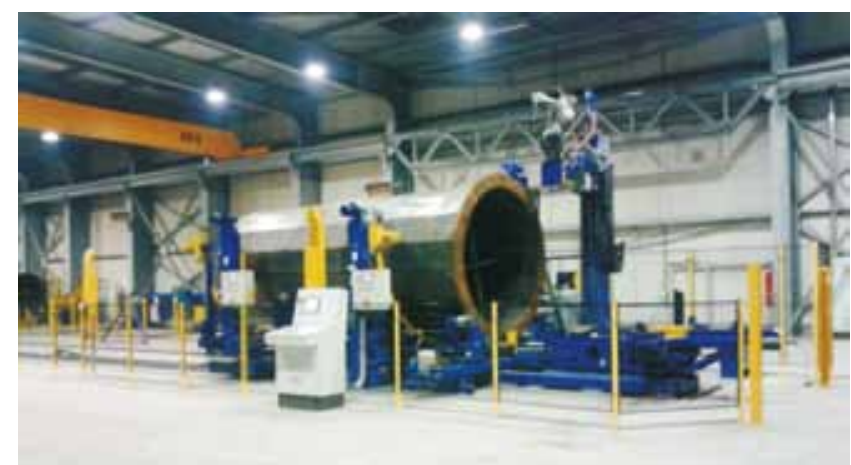

Rys. 11. Rzeczywiste zrobotyzowane stanowisko spawalnicze Fig. 11. Real robot welding system

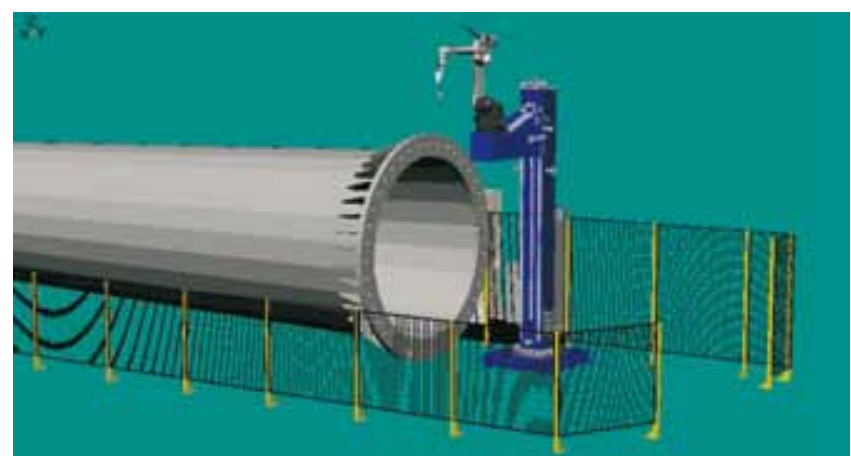

Rys. 12. Wirtualne zrobotyzowane stanowisko spawalnicze Fig. 12. Virtual robot welding system

\section{Proces kalibracji system wirtualnego}

Największą trudność stanowi połączenie idealnego systemu wirtualnego z systemem rzeczywistym, który obarczony jest błędami wymiarowymi wynikającymi głównie z tolerancji wykonania komponentów składowych systemu, np. konstrukcji nośnych, dokładności samego robota oraz odpowiedniego przygotowania przyrządów spawalniczych czy samego detalu spawanego.
W celu precyzyjnego połączenia środowiska wirtualnego z rzeczywistym należy przeprowadzić proces kalibracji systemu wirtualnego, aby był wiernym odwzorowaniem systemu rzeczywistego.

Jako przykład przedstawiono zrobotyzowane stanowisko z dwoma osiami zewnętrznymi (rys. 13).

Jedna z osi realizuje obrót spawanego detalu dookoła własnej osi, druga jest osią przesuwną dającą ruch robota na suporcie góra/dół.

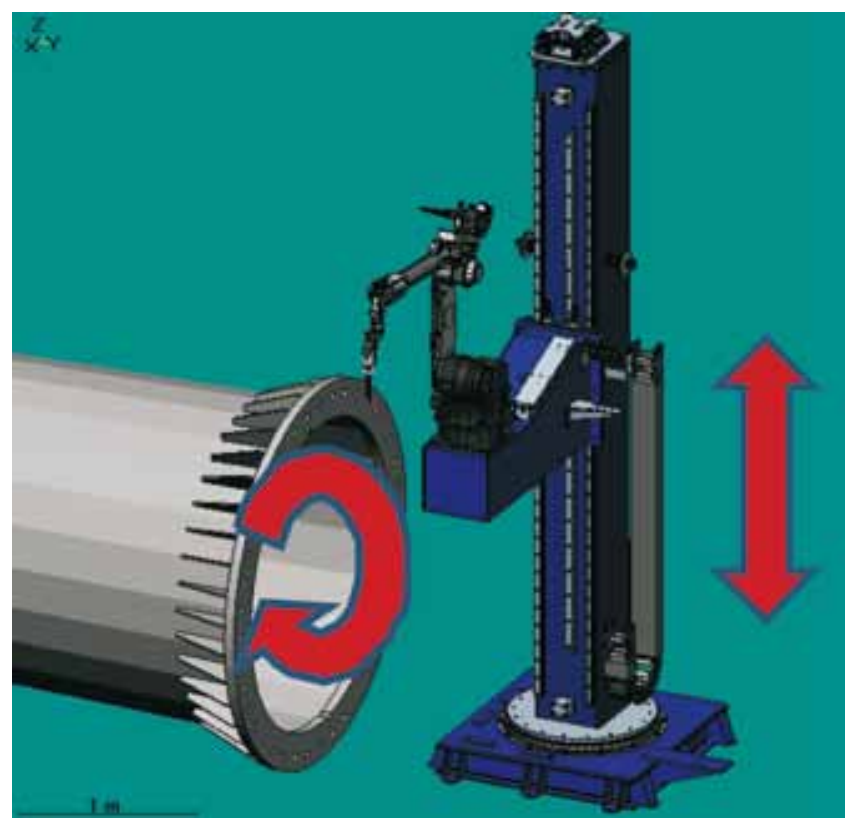

Rys. 13. Zrobotyzowane stanowisko spawalnicze z osią przesuwną i obrotową

Fig. 13. Robot welding system with shift axis and rotation axis

Proces kalibracji można podzielić na następujące etapy:

- Kalibracja ramienia robota na słupowysięgniku (rys. 14) - należy wskazać zapisane wcześniej na rzeczywistym robocie dwa punkty referencyjne określające to samo położenie ramienia robota $\mathrm{w}$ przestrzeni, ale $z$ różnym położeniem suportu, do którego jest przytwierdzony.

- Kalibracja zewnętrznej osi przesuwnej góra/dół (rys. 16) - należy wskazać zapisane wcześniej na rzeczywistym robocie trzy punkty referencyjne określające położenie wózka jezdnego w dwóch położeniach w przestrzeni oraz te same punkty na wirtualnym modelu.

- Kalibracja zewnętrznej osi obrotowej - osi detalu (rys. 15) - należy wskazać zapisane wcześniej na rzeczywistym robocie 3 punkty referencyjne określające płaszczyznę obrotu detalu spawalnego, przy założeniu, że punkty były zapisywane kolejno dla położenia $-45^{\circ}, 0^{\circ},+45^{\circ}$.

- Obliczenie przełożenia - obrót osi zewnętrznej realizowany jest przez robot, jako kolejne przełożenie (rys. 17), które zmienia się wraz ze średnicą spawanego słupa. W tym celu został napisany specjalny skrypt, który oblicza końcowe przełożenie względem zmiennej średnicy detalu. 


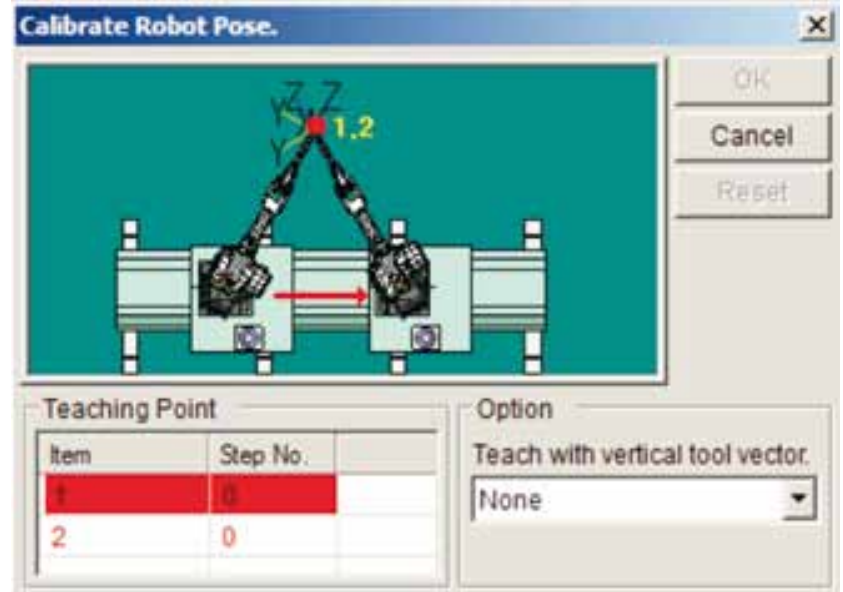

Rys. 14 Kalibracja ramienia robota

Fig. 14 Calibration of robotic arm

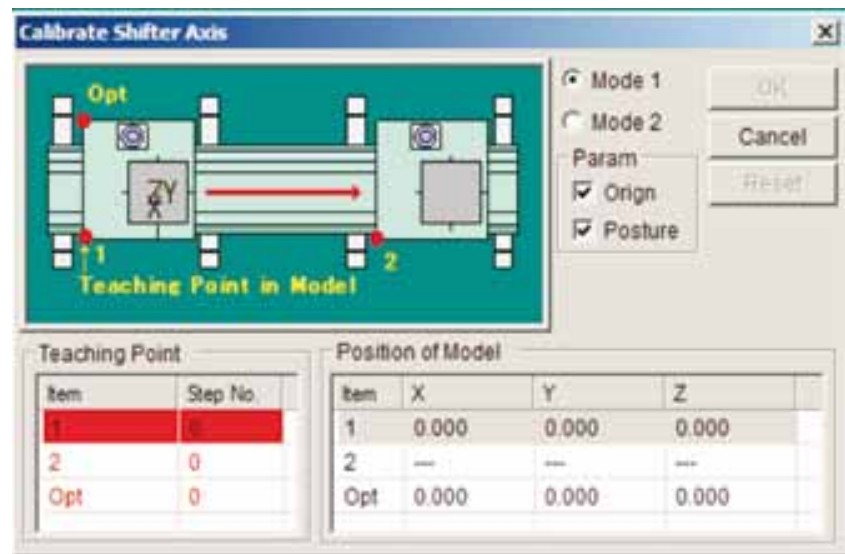

Rys. 15. Kalibracja osi przesuwnej

Fig. 15. Calibration of shift axis

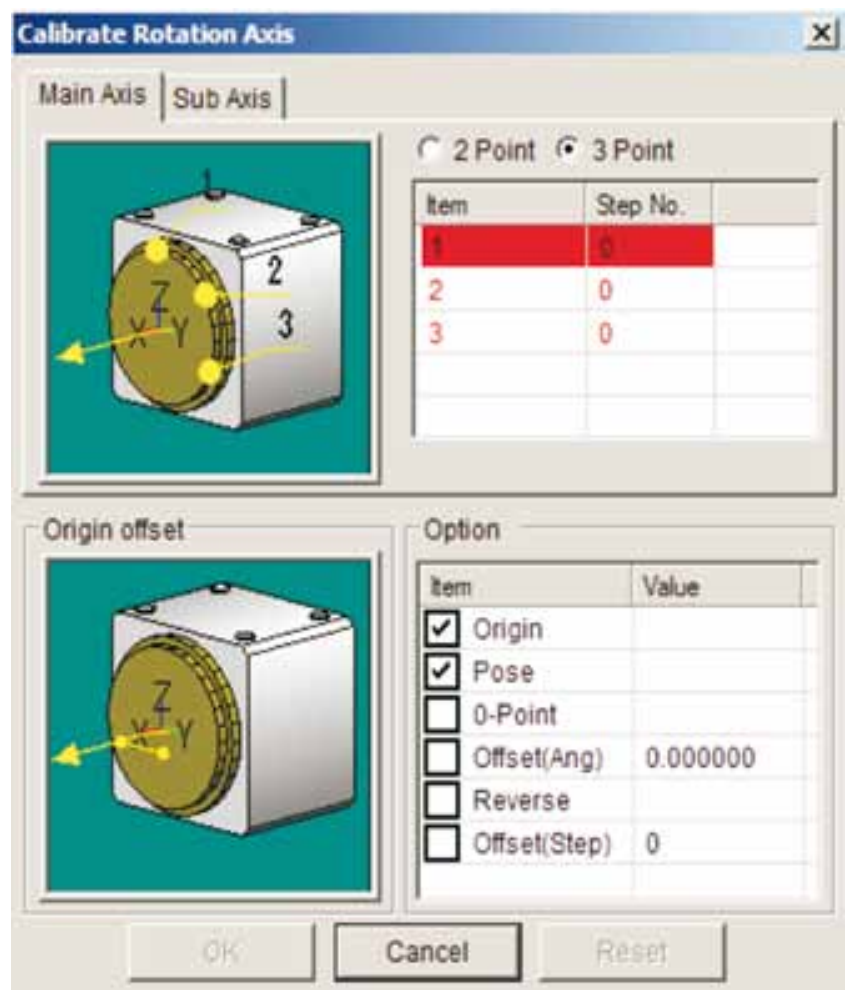

Rys. 16. Kalibracja osi obrotowej

Fig. 16. Calibration of rotation axis

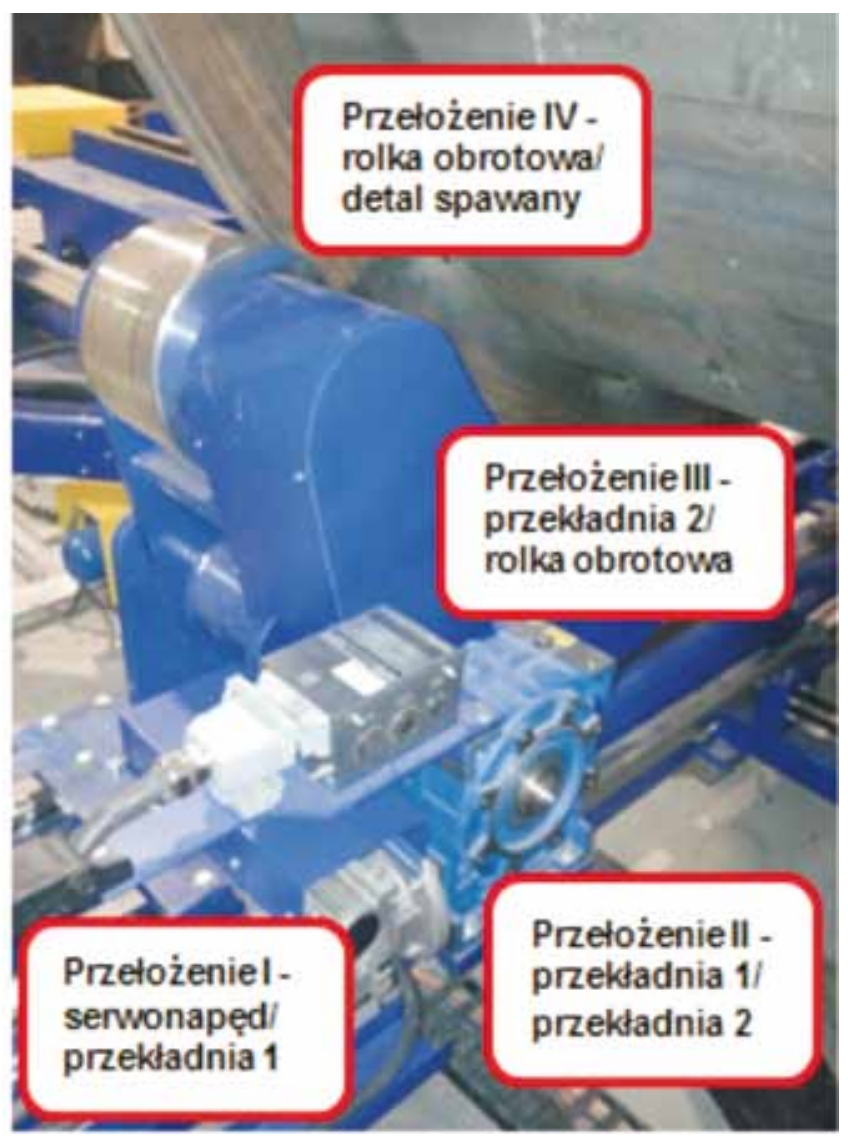

Rys. 17. Zdjęcie obrotnika rolkowego do spawania słupów energetycznych

Fig. 17. Photo of roller positioner for welding energetic pillars

Dane te muszą być każdorazowo wprowadzane do systemu zrobotyzowanego w przypadku spawania nowego detalu. Gdyby danych nie wprowadzono lub zostałyby obliczone błędnie, podstawa słupa zamiast wykonać pełny obrót $360^{\circ}$, wykona obrót większy lub mniejszy o kilka stopni. Spowoduje to desynchronizację pracy harmonicznej robota $z$ obracanym elementem.

\section{Nowy Sensor dotyku}

Najnowsza wersja sensora dotyku opracowana przez firmę Panasonic przeznaczona jest specjalnie do aplikacji, w których zachodzi potrzeba użycia dużej ilości punktów szukania przesunięć elementu spawanego. Software niniejszego sensora zawiera bibliotekę $z$ bogatą gamą ruchów robota zarówno względem układu narzędzia, jak i układu globalnego. Po wstawieniu polecenia $z$ odpowiednim kierunkiem ruchu ramię robota zaczyna wykonywać operację szukania do momentu wykrycia detalu. W chwili dotknięcia ramię jest automatycznie zatrzymywane, a punkt $z$ aktualną pozycją zapisywany (rys. 18).

$\mathrm{Na}$ rysunku 18 przedstawiono fragment programu (rys. 19) pokazujący kompletną sekwencję szukania: punkt początkowy operacji szukania P2, następnie polecenie SLS TCH 14, które zawiera informację o kierunku szukania, punkt P3 automatycznie dodany przez algorytm sensora dotyku. 


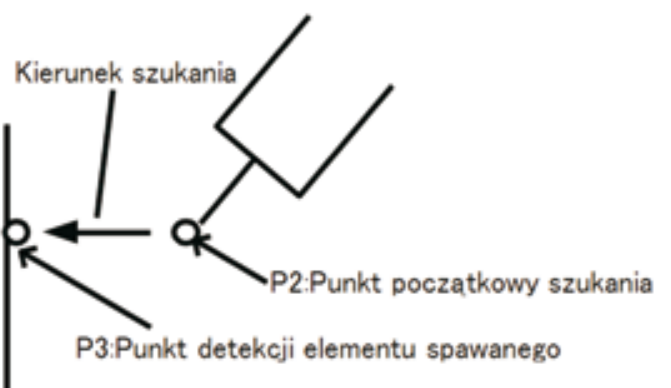

Rys. 18. Zasada działania nowego sensora dotyku z automatyczną detekcją punktu styku

Fig. 18. The principle of operation of touch sensor with automatic detection of contact point

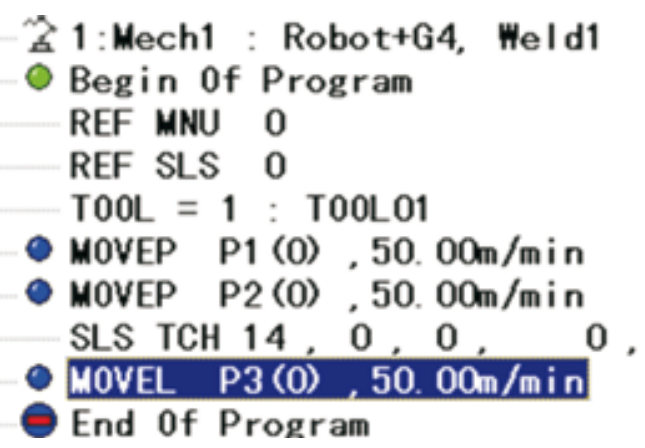

Rys. 19. Fragment programu z sekwencją nowego sensora dotyku Fig. 19. Part of program code with new Touch Sensor sequence

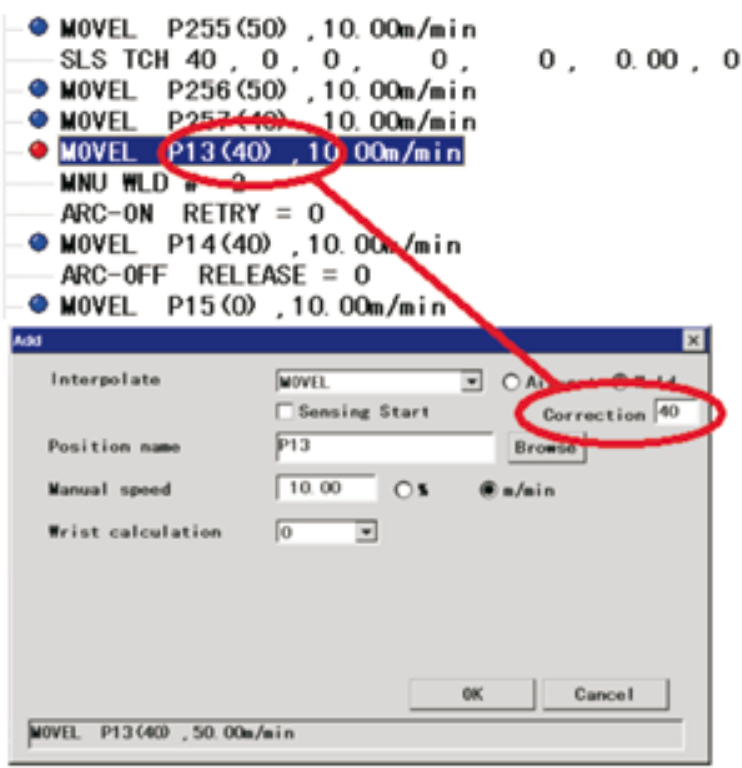

Rys. 20. Przykładowa numeracja przesunięć sensora dotyku Fig. 20. Example numeration of Touch Sensor shift

Takie rozwiązanie znacznie przyspiesza pisanie programu z wykorzystaniem rzeczywistego stanowiska zrobotyzowanego.

Dodatkowo dla polepszenia przejrzystości kodu programu wprowadzono numerację zapisanych przesunięć. W przykładzie na rysunku 20 dodano do punktu spawania P13 wartość przesunięcia nr 40. Sama wartość przesunięcia natomiast została utworzona 3 linijki wcześniej w poleceniu SLS TCH 40.
Na dzień dzisiejszy dostępne są dwie wersje nowego sensora dotyku; standardowa oraz rozszerzona przeznaczona dla blach ukosowanych. Każdą z wersji opisano w podrozdziałach dalej.

\section{Sensor dotyku standardowy - Touch sensor Function}

Zawiera podstawowe biblioteki ruchu ramienia robota wykrywające detal spawany (rys. 21). Mamy możliwość poruszania się $\mathrm{w}$ układzie robota $X+, X-$, $\mathrm{Y}+, \mathrm{Y}-, \mathrm{Z}+, \mathrm{Z}-$ oraz układzie narzędzia $\mathrm{T+}, \mathrm{T}-($ kierunek rzutowany na płaszczyznę $X, Y$ robota), $T p+$, Tp - (prostopadłe do T+ i T-), Tf (kierunek wzdłuż osi narzędzia - drutu spawalniczego), Tv+, Tv - (kierunek prostopadły do osi narzędzia).

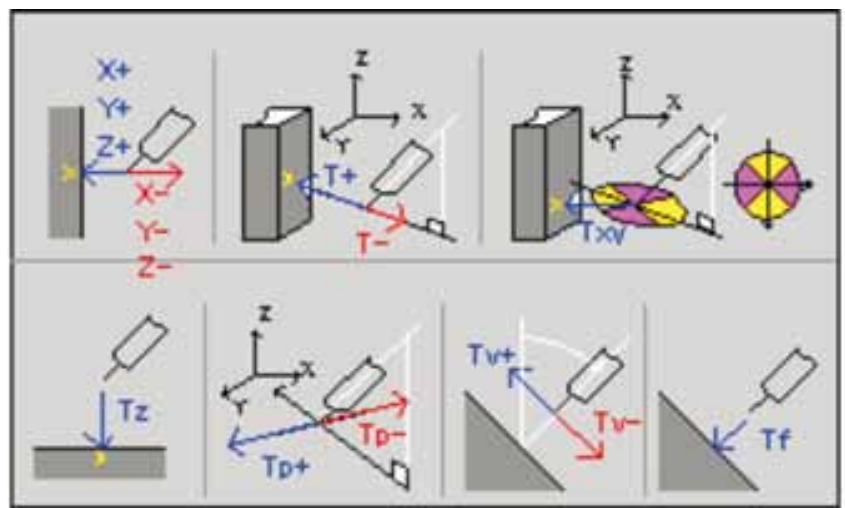

Rys. 21. Rodzaje ruchu standardowego sensora dotyku

Fig. 21. Movement type of standard Touch Sensor

\section{Sensor dotyku dla blach ukosowanych \\ - Groove Touch Sensor Function}

Wersja rozszerzona umożliwia również wykrywanie ukosowania. Pozwala to na dokładne zlokalizowanie złącza i określenie wielkości rowka spawalniczego (rys. 22). Pomiar odbywa się przez dotknięcie

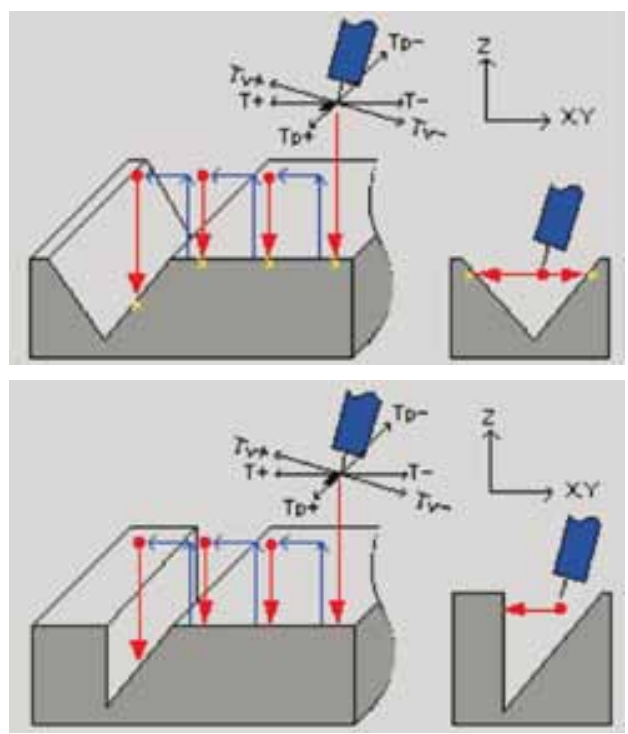

Rys. 22. Sekwencja ruchu rozszerzonego sensora dotyku dla blach ukosowanych

Fig. 22. Movement sequence of extended Touch Sensor for beveled plates 
drutem charakterystycznych punktów detalu. Aby pomiar był jak najbardziej dokładny drut, podczas pomiaru blokowany jest za pomocą siłownika pneumatycznegowspecjalnieskonstruowanymuchwyciespawalniczym Panasonic. Dodatkowo zainstalowano siłowniki w podajniku drutu, które dociskają rolki tak, aby drut się nie przemieszczał [1].

\section{Funkcja Thick Plate \\ - programowanie spoin wielościegowych}

Stosowane są dwa sposoby programowania spoin wielościegowych. Pierwsza, standardowa zakłada zapisanie każdego ściegu osobno, co jest zajęciem bardzo pracochłonnym i przysparzającym wielu trudności programistom. Druga zakłada użycie specjalnych funkcji generujących ściegi automatycznie. W tym celu firma Panasonic opracowała innowacyjny software Thick Plate. Ideą tego rozwiązania jest napisanie przez programistę jedynie pierwszego ściegu, na podstawie którego automatycznie tworzone są kolejne. Algorytm ten oczywiście uwzględnia zmianę kąta palnika i jego przesunięcie w kolejnych ściegach (rys. 23).

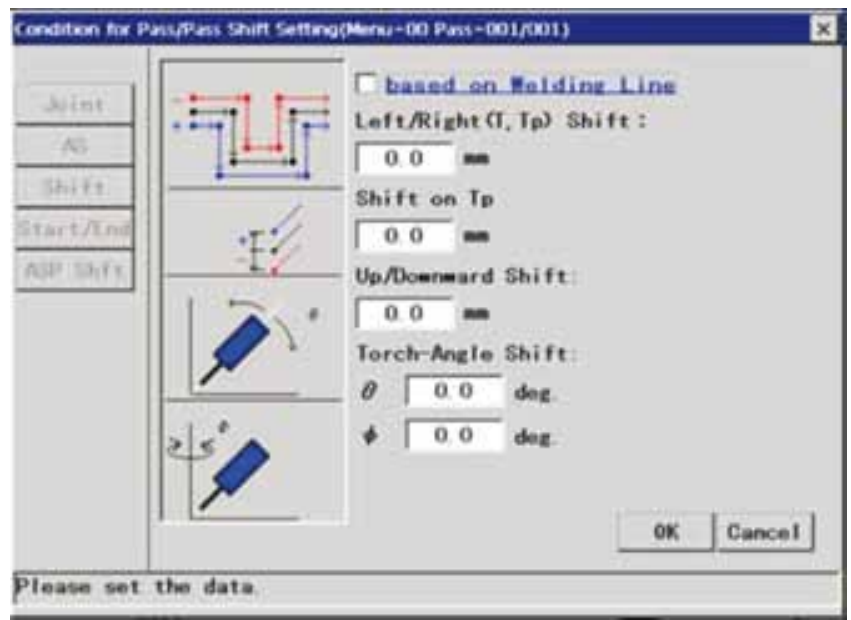

Rys. 23. Okno z parametrami funkcji Thick Plate

Fig. 23. Window with Thich Plate function parameters
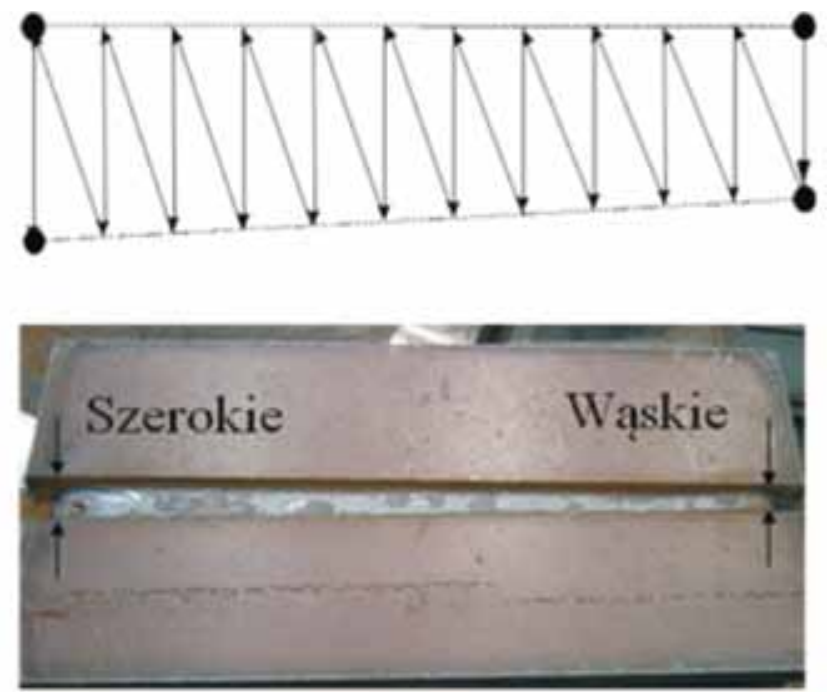

Rys. 24. Złącze wąskie w początkowym odcinku, szerokie w końcowym odcinku.

Fig. 24. Narrow joint at first section, wide at the end
Thick Plate umożliwia również spawanie złącza o nierównomiernej szerokości rowka spawalniczego. Częstotliwość ruchu oscylacyjnego dopasowuje się wówczas do zmiennej szerokości złącza (rys. 24).

\section{Touch Navi - wirtualny sensor dotyku}

Narzędzie to pozwala w sposób automatyczny wygenerować kompletną sekwencję programową wykrywania detalu sensorem dotyku w miejscach wskazanych przez programistę. Zazwyczaj są to punkty zaznaczane w trzech płaszczyznach układu kartezjańskiego $(X, Y, Z)$,w których wykonywane są przesunięcia elementu. Gdyby programista nie korzystał z Touch Navi, całą sekwencję szukania musiałby wprowadzać ręcznie, czyli punkty dojazdowe, dotyku, odjazdu oraz dodatkowe polecenia. Poniższy przykład ukazuje proces dodawania trzech punktów dotyku TS1, TS2 i TS3 spawanego żebra oraz słupa. Kierunki szukania zaznaczone są liniami czerwonymi (rys. 25).

W efekcie otrzymuje się gotową sekwencję ruchu wraz z punktami pośrednimi. W omawianym przykładzie funkcja Touch Navi stworzyła 23 wiersze kodu programu. Zawierają one m.in. polecenia aktywujące sensor dotyku, resetujące bieżące przesunięcia, ruchy dojazdowe, szukania i odjazdu. Dodatkowo algorytm dodał polecenie SNSSFTSV, które zapisuje wartość wykrytego przesunięcia do zmiennej. Na rysunku 26 pokazano graficzną reprezentację trajektorii ruchu robota. Kolor niebieski przestawia ruchy dojazdu i odjazdu od trzech miejsc szukania sensora dotyku, natomiast czarne linie reprezentują ruchy pośrednie pomiędzy tymi punktami.

Dodatkowo można według własnych preferencji określać wszystkie parametry funkcji Touch Navi (rys. 27). Tak stworzone indywidualne dane zapisywane są pod dowolną nazwą, jako własny szablon, a następnie pisząc program z wykorzystaniem funkcji Touch Navi, można je przywołać.

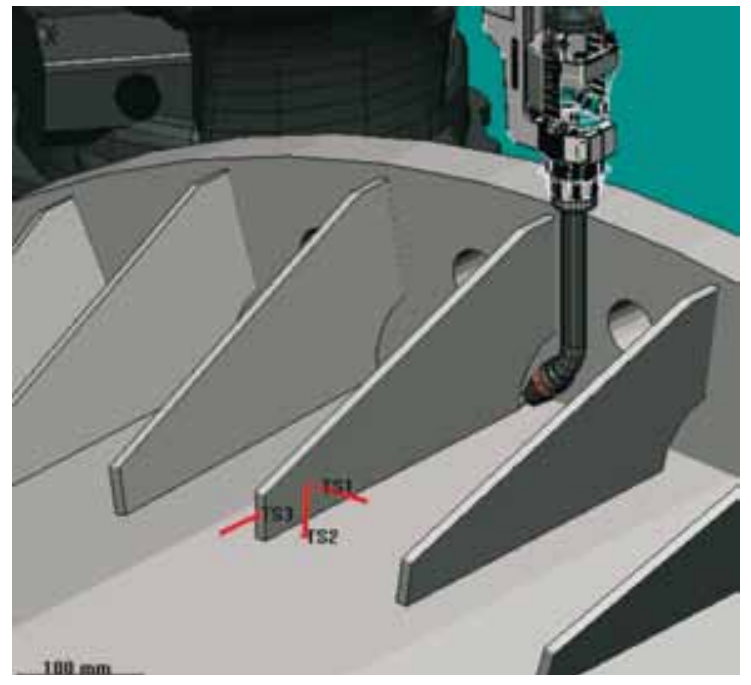

Rys. 25. Wizualizacja kierunków szukania sensora dotyku uzyskanych za pomocą funkcji Touch Navi

Fig. 25. Visualization of touching direction, obtained by Touch Navi function 


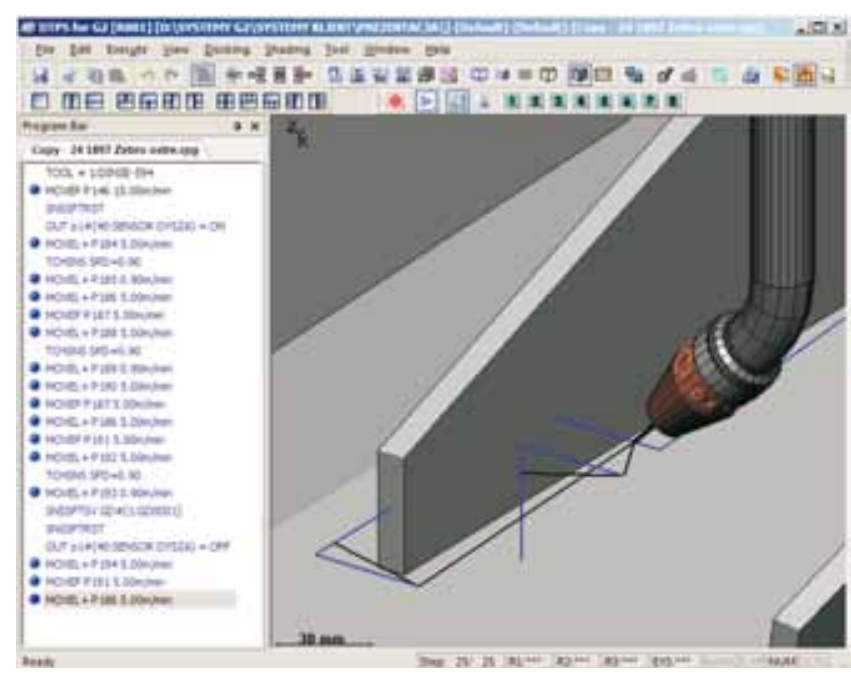

Rys. 26. Wygenerowana automatycznie sekwencja sensora dotyku za pomocą funkcji Touch Navi

Fig. 26. Automatic generation of Touch Sensor sequence using Touch Navi function

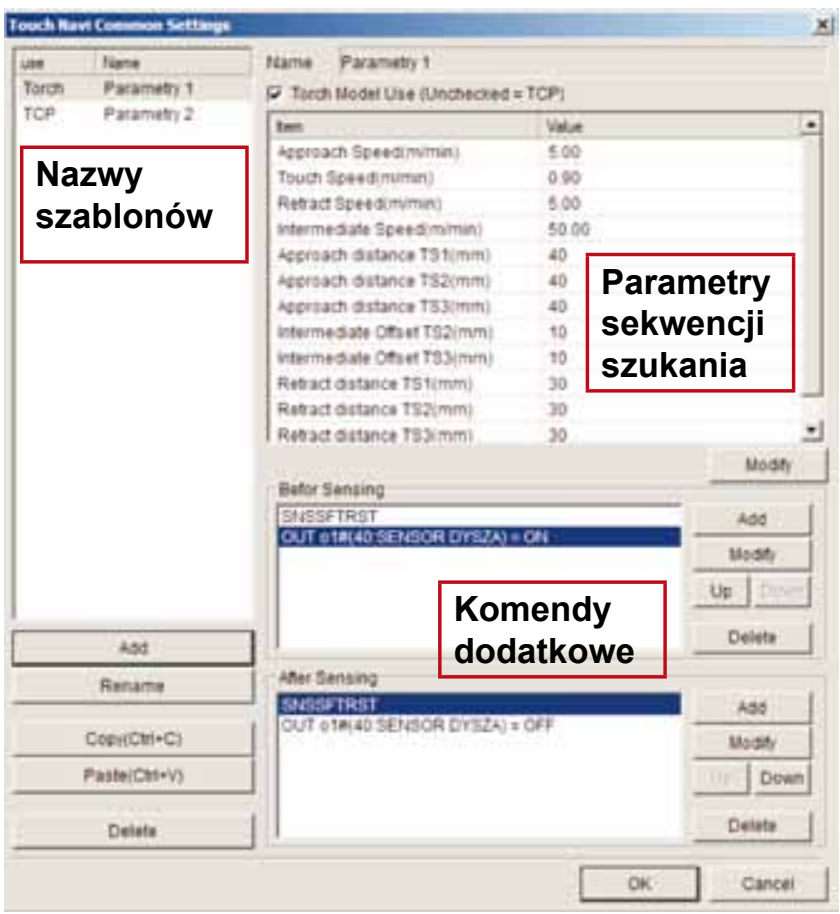

Rys. 27. Szablon z parametrami funkcji Touch Navi

Fig. 27. Template with Touch Navi parameters

Przykładowy szablon (rys. 27) o nazwie „Parametry 1" zawiera następujące dane:

- prędkość dojazdu i odjazdu $-5 \mathrm{~m} / \mathrm{min}$,

- prędkość szukania - 0,9 $\mathrm{m} / \mathrm{min}$,

- prędkość ruchów pośrednich - $50 \mathrm{~m} / \mathrm{min}$,

- odległość szukania $-40 \mathrm{~mm}$,

- odległość odjazdu - $30 \mathrm{~mm}$,

- komendy dodatkowe - wł/wy wyjścia sensora, reset przesunięć sensora.

\section{Weld Navigation - poprawne parametry spawalnicze}

Funkcja Weld Navigation (rys. 28) wspomaga w doborze odpowiednich parametrów spawania. W rezultacie nawet osoba bez dużego doświadczenia w dziedzinie spawalnictwa może $w$ łatwy sposób otrzymać dobre wyniki spawania. Funkcja ta przyspiesza również proces wykonywania prób spawalniczych, redukując tym samym czas wdrożenia detalu do cyklu produkcyjnego.

W omawianym przykładzie spawania słupów energetycznych funkcja Weld Navigation została zastosowana przy spawaniu żeber wzmacniających dla spoin pachwinowych w pozycjach PB. Przyjęto następujące założenia (rys. 29):

- rodzaj złącza - pachwinowe,

- rodzaj łuku - zwarciowy,

- grubość żebra (T1) - $10 \mathrm{~mm}$,

- grubość rury (T2) - $12 \mathrm{~mm}$,

- prędkość spawania $-0,3 \mathrm{~m} / \mathrm{min}$,

- szerokość spoiny (S) $-7 \mathrm{~mm}$.

Otrzymano następujące wyniki (rys. 29):

- wartość natężenia prądu - $219 \mathrm{~A}$,

- wartość napięcia - 19,3 V,

- wysokość spoiny (a) $-5 \mathrm{~mm}$,

- kąt palnika $-45^{\circ}$,

- offset - L2=3,8 mm w stronę materiału T2.

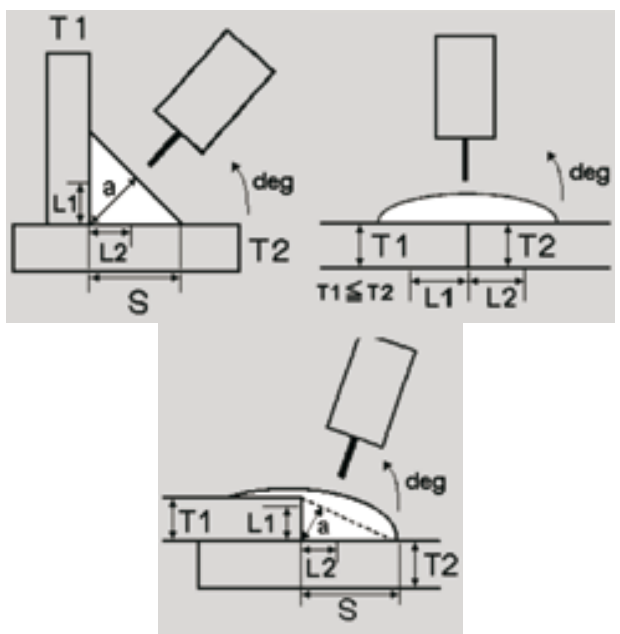

Rys. 28. Trzy rodzaje złączy spawanych dostępnych w funkcji Weld Navigation. Kolejno: pachwinowe doczołowe, nakładkowe

Fig. 28. Three types of welding joints available in Weld Navigation function. Respectively: T-joint, butt joint, lap joint

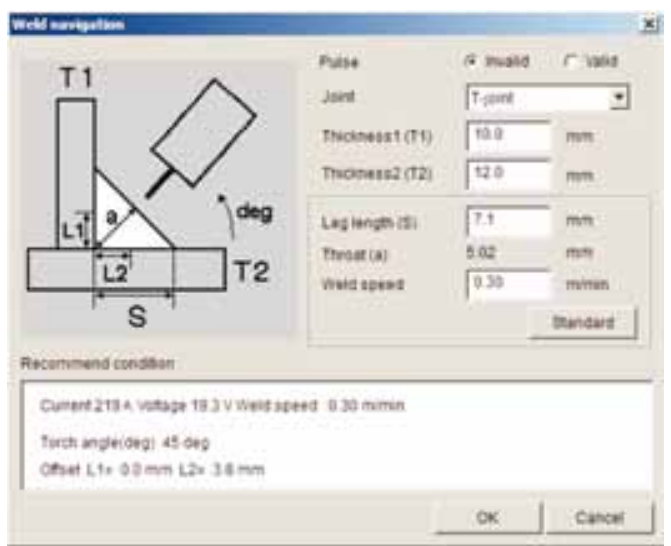

Rys. 29. Okno funkcji Weld Navigation z wprowadzonymi danymi oraz obliczonymi parametrami

Fig. 29. Window with entered data in Weld Navigation function and welding parameters as a result of calculation 
Pozostałe złącza spawane wymagały indywidualnego podejścia ze względu na różny kąt ukosowania krawędzi blach czy zmienną wysokość progu, których Weld Navigation nie uwzględnia, dobierając parametry spawania. $W$ rezultacie parametry te zostały dobrane metodą empiryczną.

\section{Przykładowe realizacje}

Na rysunkach 30-32 przedstawiono przykładowe realizacje systemów zrobotyzowanych do spawania elementów wielkogabarytowych z wykorzystaniem technologii Panasonic.

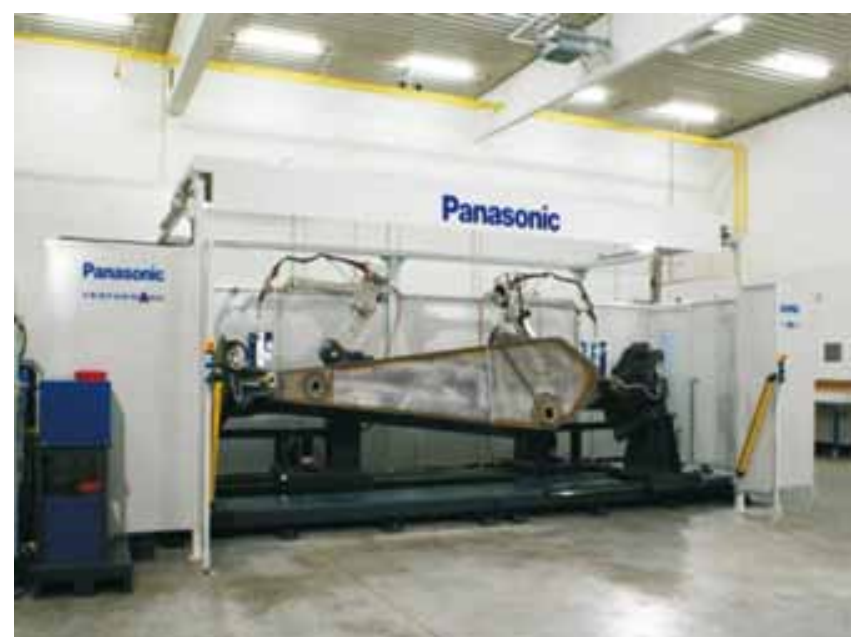

Rys. 30. Zrobotyzowany system do spawania podłużnic do koparek Fig. 30. Robot system for welding excavator boo

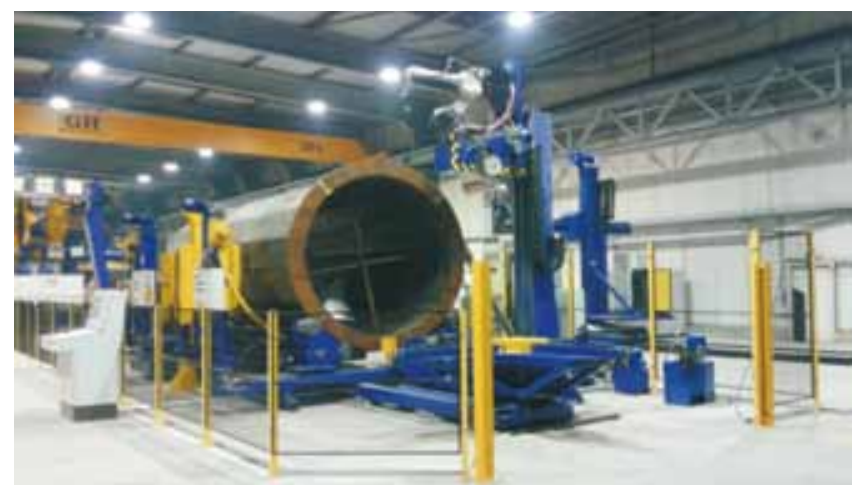

Rys. 31. Stanowisko zrobotyzowane do spawania słupów energetycznych

Fig. 31. Robot system for welding energetic pillars

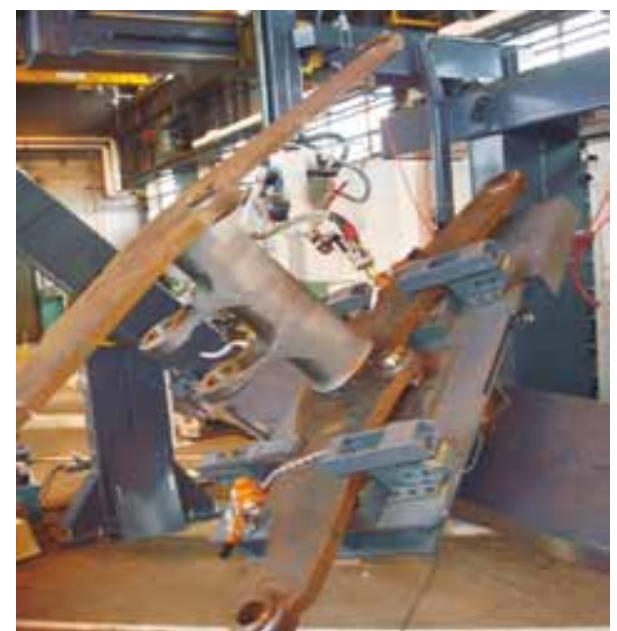

Rys. 32. Stanowisko zrobotyzowane do spawania elementów koparek. Fig. 32. Robot system for welding excavator parts

\section{Wnioski}

Spawanie zrobotyzowane elementów wielkogabarytowych bez wspomagania wirtualnym oprogramowaniem off-line jest nieekonomiczne i bardzo pracochłonne.

W systemach zrobotyzowanych Panasonic dostępne są trzy metody programowania elementów wielkogabarytowych o dużych grubościach:

- Pierwsza metoda - standardowa, nie wykorzystuje się w niej funkcji Thick Plate oraz oprogramowania off-line DTPS i związanej z nim kalibracji systemu. Jest to niezalecane, nieekonomiczne rozwiązanie oparte jedynie na sensorach dotyku i łuku.

- Druga metoda wykorzystuje funkcję Thick Plate oraz oprogramowanie off-line $z$ pełną kalibracją systemu wirtualnego z rzeczywistym. Dodatkowo stosowane są narzędzia Touch Navi, Weld
Navigation oraz nowy Sensor dotyku dla blach ukosowanych. Jest to najdroższa metoda, na którą stać nie każdą firmę produkcyjną.

- Trzecia metoda - jest pośrednia pomiędzy pierwszą a drugą. Wykorzystuje się w niej oprogramowanie DTPS, sensor dotyku i napisany autorski program spawalniczy wzorujący się na funkcji Thick Plate. Dodatkowo stosuje się też specjalny skrypt do obliczania bardziej skomplikowanych przełożeń osi zewnętrznych robota. Metoda ta jest najbardziej ekonomiczna.

Spawanie zrobotyzowane elementów wielkogabarytowych dzięki rozwojowi zaawansowanych programów off-line, sensorów czy funkcji takich jak Thick Plate będzie przeżywać w najbliższym czasie burzliwy rozwój.

\section{Literatura}

[1] Ishihara K., Nowak M., Wiśniewski D.: Robotyzacja procesu spawania elementów wielkogabarytowych, Przegląd Spawalnictwa, 6 , 2009, s. 31-33. 